\title{
The Effects of Workplace Incivility on Job Satisfaction: Mediating Role of Organizational Citizenship Behavior, Intrinsic and Extrinsic Motivation, Emotional
} Exhaustion

\author{
Rabbia Jamal (Corresponding Author) \\ Research Scholar \\ Karachi University Business School, University of Karachi, Pakistan \\ E-mail: rabbia.rj94@yahoo.com \\ Dr. Danish Ahmed Siddiqui \\ Associate Professor \\ Karachi University Business School, University of Karachi, Pakistan \\ E-mail: daanish79@ hotmail.com
}

Received: Feb. 4, 2020 Accepted: Mar. 1, 2020 Online published: Mar. 17, 2020

doi:10.5296/ijhrs.v10i2.16389

URL: https://doi.org/10.5296/ijhrs.v10i2.16389

\begin{abstract}
Scholars have baptized for investigation relating to the antecedents and sways of workplace incivility and means to condense it. To address this concern, this study proposes a theoretical framework that explains the linkages of workplace incivility (WI) with Job satisfaction (JS). We theorized that incivility decreases employees' motivation, increases emotional exhaustion and further leads to restricted OCB. These factors, in response, confine employees' job satisfaction. Further ahead, age, and gender moderates the effect of incivility on job satisfaction. Hence, OCB, exhaustion, and motivation mediate incivility and job satisfaction nexus. These relationships were theorized in a singular model to portray the overall impact of the variables occurring at once. Empirical validity was established through a survey conducted through close-ended questionnaire from 272 employees working in Karachi. Results proposed that there is a negative mediatory impact of emotional exhaustion, whereas, OCB, extrinsic and intrinsic motivation had no mediatory effect on experienced incivility and
\end{abstract}


job satisfaction. With regards to instigated incivility, it doesn't cause any significant or material job dissatisfaction, however, intrinsic motivation and emotional exhaustion play a negative mediatory role. Witnessed incivility directly affect JS as its coefficient was negative and significant, however, no mediatory role was found.

Keywords: workplace incivility, organizational citizenship behavior, motivation, emotional exhaustion, job satisfaction, structural equation modeling

\section{Introduction}

Past research works have revealed that insolent, impolite, or uncivil behaviors at the workplace can be the potentially persistent form of workplace maltreatment also known as workplace incivility (WI) (Cortina, 2008). As indicated by Andersson and Pearson (1999), WI can be defined as, "a particular form of low-intensity deviance at work which is distinguished from workplace aggression by its ambiguous intent to harm targets". Uncivil behavior at the workplace has unfavorable effects on worker and organizational outcomes due to the substantial outlay it causes to the besieged employees, their coworkers, and the organization at large (Sakurai \& Jex, 2012).

A qualitative analysis of literature divides workplace incivility into three distinct, yet interrelated areas as experienced incivility (EI), instigated incivility (II) and witnessed incivility. EI caters to the thoughts, feelings and subsequent behaviors of employees who are targets of uncivil behavior. Instigated incivility captures the instigators of incivility and witnessed incivility captures the relationship of witnessing uncivil behavior at the workplace (Schilpzand, 2016).

Workplace incivility often produces deleterious work reactions, for example, emotional exhaustion can potentially lead to an increase in job dissatisfaction (Sliter et al., 2012). Correspondingly, workplace incivility has also shown to aggravate emotional exhaustion among workers (Dorman \& Zapf, 2004), and hence, unfavorably moves job satisfaction.

EI and II are the two primary categories of WI that have been frequently researched, however, fewer researches have been conducted regarding witnessed incivility (Schilpzand, 2016). Most of the prevailing work tends to emphasize only on the adverse impacts of either EI or II on employee and organizational outcomes (Cortina \& Magley, 2009). In connection with that, preceding researches have overlooked the greater effects of witnessed incivility. Schilpzand (2016) in his research found that out of 55 researches performed on workplace incivility, only 4 researches attempted to address the impacts of witnessed incivility at the workplace.

However, there have been few numbers of researches that caters to the problems undermining workplace incivility and job performance in the context of Pakistani workplace and employee, employer relations. There has been a little effort to analyze the impact of workplace incivility of co-workers and their detrimental impacts on job performance and satisfaction. The following research is an attempt to fill this gap by analyzing the above empirical gaps existing and providing Pakistani organizations to reduce the tendency of this un-civil behavior at the workplace by introducing organizational citizenship behavior (OCB) and means of increasing the intrinsic motivational factors. The counterproductive impacts of 
workplace incivility can be minimized to a level that it can barely impact the organizational resources and performance.

The current study is an effort to outline a theoretical model of how different types of workplace incivility influence job satisfaction simultaneously. Moreover, the present research sightsees the mediating via which WI can be influential on job satisfaction (JS) in the presence of emotional exhaustion (EE), intrinsic motivation (IM), extrinsic motivation (EM) and organizational citizenship behavior (OCB) as mediators. Lastly, this research explores the moderating mechanism of gender and years of experience, influencing the relationship between WI and JS. The research is an attempt to provide the organizational implications in terms of how workplace incivility evolves and how it can be a deteriorating factor for work motivation and OCB.

\section{Background to the Literature and Hypothesis}

\subsection{Job Satisfaction and Workplace Incivility}

The definition of workplace incivility, often cited in literature, defines WI as: "Low-intensity behavior with ambiguous intent to harm the target, in violation of workplace norms for mutual respect; uncivil behaviors are characteristically rude and discourteous, displaying a lack of regard for others" (Andersson \& Pearson, 1999). Past researches have shown that EI is associated with counterproductive behaviors and responses. For example, Bunk and Magley (2013) identified that experienced incivility produces a tendency to reciprocating the behavior. Kim and Shapiro (2008) argue that it brings retaliation, Lim and Teo (2009) argued that it causes deviant behavior and Penny and Spector (2005) provided evidences of counterproductive behavior at work.

Witnessed incivility is defined as, "the type of incivility dealing with the feelings, thoughts, and behaviors and other correlates of employee who are the witness of uncivil behavior at workplace." (Schilpzand, 2016). Witnessed incivility is an emerging range of studies with opportunities and cavities in future researches (Schilpzand, 2016). According to Montgomery et al. (2004), females have a greater tendency of witnessing workplace incivility than men does. Porath and Erez (2009) argued that witnessing incivility at the workplace causes negative impacts and reduces the tendency of creative performance, organizational citizenship behavior and job satisfaction. Whereas, Totterdell et al. (2012) established that WI causes emotional exhaustion.

Instigated incivility is defined as, "the type of workplace incivility that caters the instigators of workplace incivility directed toward employees and assess its antecedents and outcomes." (Schilpzand, 2016). According to research conducted by Blau and Anderson (2005), which examined the effects of II on distributive justice, JS, and EE. The findings implied that job satisfaction and distributive justice were adversely related to instigated incivility, whereas, emotional exhaustion had a positive relation with instigated incivility. The research conducted was a longitudinal study performed on working adults, particularly targeting co-workers and supervisors.

Torkelson et al. (2016) conducted research in the context of the Swedish working population. 


\section{Macrothink

He used a stratified sampling technique and found that $52 \%$ of the population had been the target of incivility instigated by supervisors and $73 \%$ of the people faced some form of incivility through co-workers in the past year. In a similar capacity, Reio and Trudel (2013) conducted research on a group of United States healthcare workers and found that $75 \%$ of the sample experienced incivility and approximately $30 \%$ of the sample faced incivility, ranging from, sometimes to always. They used the multiple regression analysis and the outcomes implied that the people being the target of the workplace incivility had poor organizational commitment, contextual performance, and greater turnover intent. Based on the empirical evidences, we imply that:

H1: There exists a negative and significant relationship between EI and OCB.

H2: There exists a negative and significant relationship between EI and IM.

H3: There exists a negative and significant relationship between EI and EM.

H4: There exists a positive and significant relationship between EI and EE.

H5: There exists a negative and significant relationship between II and OCB.

H6: There exists a negative and significant relationship between II and IM.

H7: There exists a negative and significant relationship between II and EM.

H8: There exists a positive and significant relationship between II and EE.

H9: There exists a negative and significant relationship between witnessed incivility and $O C B$.

H10: There exists a negative and significant relationship between witnessed incivility and IM.

H11: There exists a negative and significant relationship between witnessed incivility and EM.

H12: There exists a positive and significant relationship between witnessed incivility and EE.

H13: There exists a negative and significant relationship between EI and JS.

H14: There exists a negative and significant relationship between II and JS.

H15: There exists a negative and significant relationship between witnessed incivility and JS.

\subsection{Workplace Incivility and Organizational Citizenship Behavior}

Organ (1988) defined OCB as: "Organizational citizenship behavior (OCB) refers to employees' discretionary behaviors that go above and beyond their prescribed job responsibilities to help others in the workplace in achieving the organizational goal". Aquino and Thau (2009) argued that experiencing incivility and portraying OCB has a very close relation. Particularly, according to Aquino and Bommer (2003) people who participated greater in OCB had lesser chances of experiencing incivility because individuals who participates more in OCB tend to increase their social attractiveness and thus have minimum 
chances of experiencing incivility at the workplace (Bolino, 1999). Porath and Erez (2009) found that witnessing WI at the workplace causes employees to reduce their engagement in OCB. Whereas, Mao et al. (2019) argued that experiencing WI adversely predicted OCB among individuals and leading to job dissatisfaction. Taylor et al. (2012) argued that workplace incivility negatively affects $\mathrm{OCB}$, this is due to the fact that the targets thinks that the social exchange relationship is deteriorating between them and the organization. It may also be implied that the workplace incivility reduces the tendency of portraying OCB in the presence of emotional exhaustion (Jawahar \& Schreurs, 2018). Based on the empirical evidence we imply that:

H16: $O C B$ has a positive and significant impact on JS.

H17: OCB will significantly mediate the relationship between EI and JS.

H18: $O C B$ will significantly mediate the relationship between II and JS.

H19: $O C B$ will significantly mediate the relationship between witnessed incivility and JS.

\subsection{Workplace Incivility and Motivation}

Amabile (1996) viewed intrinsic motivation as the readiness or aspiration to upsurge effort because of the delightfulness of the work. However, people experiencing incivility are less likely to increase their desire for work enjoyment in order to protect their resources. Workplace incivility depletes the emotional resources of the employee working and thus employees are less interested in performing tasks with keen desire and aspiration.

Cortina et al. (2001) in her research argued that extrinsic motivation can have no impact on the relationship of WI and JS. The research conducted was based on the impacts of instigators and experiences of incivility at the workplace pertaining to their fluctuating tendencies in different genders. The research implied that extrinsic motivation refers to the monetary benefits which in any way cannot be impacted by the incivility, however, the researcher implied to testify its no existing relationship.

According to Gagne and Forest (2010), IM tends to increase positive consequences, productive performance and adversely impacts employee withdrawal. The results indicated that external and introjected regulation were connected to EE, physical and mental problems. However, integrated and identified regulations had been positively impacting job performance and lower turnover intention. Based on the empirical evidence we imply that:

H20: IM has a positive and significant impact on JS.

H21: There exists a significant mediating role of IM between EI and JS.

H22: There exists a significant mediating role of IM between II and JS.

H23: There exists a significant mediating role of IM between witnessed incivility and JS.

H24: EM has a positive and significant impact on JS.

H25: There exists a significant mediating role of EM between EI and JS. 
H26: There exists a significant mediating role of EM between II and JS.

H27: There exists a significant mediating role of EM between witnessed incivility and JS.

\subsection{Workplace Incivility and Emotional Exhaustion}

Maslach and Jackson (1981) defined EE as: "feelings of emotional helplessness and the depletion of an individual's emotional resources". Aiken et al. (2002) analyzed a data set pertaining to Pennsylvania as part of the International hospital outcomes study. The research examined the relationship between patient to nurse ratio of EE and JS. The results of the research implied that higher tendency of EE was positively and significantly related to higher job dissatisfaction. Moreover, the results showed that an increase in patient per nurse caused a $15 \%$ decrease in JS and a $23 \%$ increase in EE.

The levels of EE are linked with the levels of tolerance, employees, have for their colleagues and clients (Leiter \& Maslach, 1988). Uncivil behaviors from coworkers become a primary foundation of stress by draining a targeted employee's expressive energy and intellectual resources (Laschinger et al., 2009). Coworker incivility comprises distinctive behaviors with vague intent to detriment the oppressed, such as deserting to say "please" or "thank you", overlooking or levitating voice (Pearson et al., 2000), These are associated with undesirable outcomes such as amplified EE (Laschinger et al., 2009; Sliter et al., 2012) and cut mental well-being (Lim \& Cortina, 2008). Based on the empirical evidence we imply that:

H28: EE has a negative and significant impact on JS.

H29: There exists a significant mediating role of EE between EI and JS.

H30: There exists a significant mediating role of EE between II and JS.

H31: There exists a significant mediating role of EE between WI and JS.

\subsection{Workplace Incivility and Gender}

Past researches have suggested that the WI is a gendered variable of workplace environment and females are the easiest target of workplace incivility than men (Cortina, 2008; Pearson et al., 2000). According to research conducted by Rubino and Cortina (2004), women who observed uncivil work behaviors at work had lower job and health satisfaction. During the observation, it was found that women who experience incivility have a greater tendency of increasing exhaustion, disengagement and lowers JS, physical and psychological well-being (Miner-Rubino \& Cortina, 2007). The theorized concept related is based on the empirical pieces of evidence provided from the past. Past researches imply that females have a greater tendency of getting impacted by workplace incivility and reduced job satisfaction. Based on the aforementioned arguments, we expect that:

H32: Gender will moderate the relationship between WI and JS.

\subsection{Workplace Incivility and Work Experience}

There is a lack of research on the moderating role of years of experience between WI and JS, according to Yeung and Griffin (2008), who argued that years of experience may cause 


\section{Macrothink}

International Journal of Human Resource Studies

ISSN 2162-3058 2020, Vol. 10, No. 2

employees to experience and instigate, less or more uncivil behavior at the workplace. The results implied that employees having less than six months of experience experienced significantly less uncivil behavior than employees having experience greater than six months. The research implied the first six months of experience as the "honeymoon" period after which employees start experiencing the same uncivil behavior and hence increasing job dissatisfaction level. Based on the empirical pieces of evidence, we theorize that the greater years of experience tend to have greater experiences of workplace incivility and lesser years of experience tend to have lower experiences of workplace incivility. Based on the aforementioned arguments, we expect that:

H33: Work experience will moderate the relationship between WI and JS.

\section{Method}

\subsection{Hypothesized Model}

The hypothesized model contained 82 item out of which three incivility scales (12 items each), experienced, instigated and witnessed, OCB (10 items), IM (3 items), 4 scales of EM (3 items each), introjected regulation, integrated regulation, identified regulation and external regulation, EE ( 7 items) and JS ( 10 items). The model also contained two demographic variables, gender and years of experience as moderator between workplace incivility and job satisfaction.

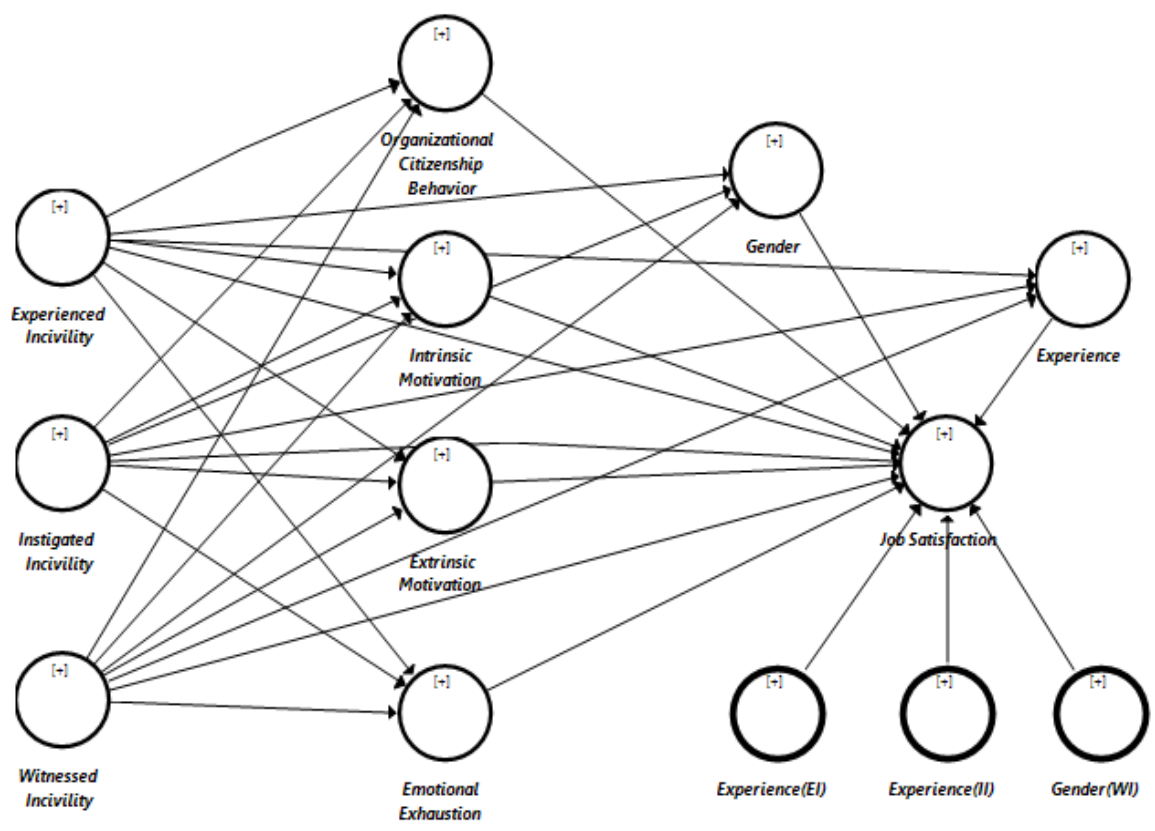

Figure 1. Hypothesized Model 


\subsection{Data Collection and Participant Characteristics}

\subsubsection{Demographic Characteristics}

The survey instrument also included four demographic questions relating to the length of service, gender, education, and age to gather demographic characteristics of the respondents (see table 1). Whereas, gender and length of services were also used as a moderating variable between workplace incivility and job satisfaction.

Table 1. Descriptive Statistics of demographic characteristics

\begin{tabular}{|c|c|c|c|}
\hline & & Frequency & Percent \\
\hline \multirow{2}{*}{ Gender } & Male & 153 & 76.5 \\
\hline & Female & 47 & 23.5 \\
\hline \multirow{9}{*}{ Age } & 20-24 years & 53 & 26.5 \\
\hline & 25-29 years & 80 & 40 \\
\hline & 30-34 years & 34 & 17 \\
\hline & 35-39 years & 18 & 9 \\
\hline & 40-44 years & 6 & 3 \\
\hline & 45-49 years & 4 & 2 \\
\hline & $50-54$ years & 1 & 0.5 \\
\hline & $55-59$ years & 3 & 1.5 \\
\hline & 60 Above & 1 & 0.5 \\
\hline \multirow{5}{*}{ Education } & Intermediate & 10 & 5 \\
\hline & Graduation & 88 & 44 \\
\hline & Post-Graduation & 75 & 37.5 \\
\hline & M.Phil./ PhD & 15 & 7.5 \\
\hline & Other & 12 & 6 \\
\hline
\end{tabular}




\begin{tabular}{|c|c|c|c|}
\hline \multirow{4}{*}{} & $0-6$ months & 16 & 8 \\
\cline { 2 - 4 } & $7-11$ months & 14 & 7 \\
\cline { 2 - 4 } Years of Experience & $1-2$ years & 40 & 20 \\
\cline { 2 - 4 } & 3-5 years & 55 & 27.5 \\
\cline { 2 - 4 } & $6-10$ years & 35 & 17.5 \\
\cline { 2 - 4 } & $11-15$ years & 25 & 12.5 \\
\cline { 2 - 4 } & More than 15 years & 15 & 7.5 \\
\hline
\end{tabular}

The data for the study was collected using a survey questionnaire instrument, from 272 employees working in different organizations in Pakistan, specifically in Karachi. The respondents belonged to the services industry operating in Pakistan. $75 \%$ of the respondents were male and $25 \%$ of the respondents were female $(\mathrm{SD}=0.431)$ having an average age of 25-29 years $(\mathrm{SD}=1.427)$. Most of the respondent's education was above graduation $(\mathrm{SD}=$ $0.905)$ and the average experience of the respondents was 3-5 years $(\mathrm{SD}=1.614)$.

\subsection{Measurement Scales}

All of the selected scales were English-based. Four, Five and Seven points Likert- scales were used to measure the responses of all the constructs respectively which are further discussed.

\subsubsection{Workplace Incivility}

All of the types of WI which are, experienced, instigated and witnessed were measured using a 12- item instrument developed by adopting 7- items from Cortina et al. (2001) and 5 items from Chihak (2018). These 12 items were measured using a 4-point liker scale (1= "Hardly ever"; 4= "Frequent"). The responses were averaged on 4- point scale, where a higher score represents the greater tendency of WI. The reliability of the instrument was measured using Cronbach's $\alpha$ (Nunnally, 1978). The internal consistency reliability of this instrument was $0.84,0.88$ and 0.89 respectively.

\subsubsection{Organizational Citizenship Behavior}

A 10-item scale was adopted from Spector et al. (2010). These 10 items were measured using a 5-point Likert-scale (1= "Never"; 5= "Everyday"). The responses were averaged on 5- point scale, where a higher score represents the greater tendency of OCB. The reliability of the instrument was measured using Cronbach's $\alpha$ (Nunnally, 1978). The internal consistency reliability of this instrument was 0.79 . 


\subsubsection{Motivation}

A 3-item and 12-item scale were adopted by Tremblay et al. (2009) for IM and EM respectively. These items were altogether measured using a 7-point Likert-scale (1= "Corresponds not at all"; 7= "Corresponds exactly"). The responses were averaged on 7point scale, where a higher score represents the greater tendency of motivation. The reliability of the instrument was measured using Cronbach's a (Nunnally, 1978). The internal consistency reliabilities of these instruments were 0.81 and 0.91 respectively.

\subsubsection{Emotional Exhaustion}

A 7-item scale was adopted from the Maslach Burnout Inventory (MBI) developed by Maslach (1981). MBI has three components namely: exhaustion, depersonalization, and personal achievement, out of them only emotional exhaustion has been adapted to record the responses. These 7 items were measured using a 7-point Likert-scale (1= "Never"; 7= "Everyday"). The responses were averaged on 7- point scale, where a higher score represents the greater tendency of EE. The reliability of the instrument was measured using Cronbach's $\alpha$ (Nunnally, 1978). The internal consistency reliability of this instrument was 0.82 .

\subsubsection{Job Satisfaction}

A 10-item scale was adopted from Macdonald and MacIntyre (1997). These 10 items were measured using a 5-point Likert-scale (1= "Strongly Disagree"; 5= "Strongly Agree"). The responses were averaged on 5- point scale, where a higher score represents the greater tendency of JS. The reliability of the instrument was measured using Cronbach's $\alpha$ (Nunnally, 1978). The internal consistency reliability of this instrument was 0.85 .

\section{Results and Data Analysis}

\subsection{Data Analysis}

Data analysis was performed using the SMART- PLS-SEM version 3.2.8 which is a leading software tool for partial least square structural equation modeling (Ringle et al., 2015). Ringle (2018) argued that out of 77 studies conducted, 65 studies (84.4\%) used PLS-SEM in their analysis. The research also implied that it is reasonable to use PLS-SEM in the context of HRM studies. The reason for using PLS-SEM in HRM context is the sample size, non-normal data and use of categorical variables (Ringle, 2018). It is argued that these aspects are less emphasized in HRM as compared to other business research disciplines that's why it is recommended to use PLS-SEM (Hair et al., 2012).

\subsection{Reliability}

The measurement scales used to record the responses of the participants were tested for validity and reliability using a common validation process. Firstly, the constructs' reliability factor was tested using Cronbach's alpha coefficients (see table 2). According to Nunnally (1978), the reliability of the constructs is considered normal if it is >0.6. The variable's reliability coefficients ranged from 0.79 to 0.9 , which is considered normal. 
Table 2. Reliabilities of the variables

\begin{tabular}{|l|l|l|}
\hline Variables & Cronbach's Alpha & rho_A \\
\hline Emotional Exhaustion & 0.82 & 0.86 \\
\hline Experienced Incivility & 0.84 & 0.85 \\
\hline Instigated Incivility & 0.88 & 0.88 \\
\hline Intrinsic Motivation & 0.81 & 0.82 \\
\hline Job Satisfaction & 0.85 & 0.85 \\
\hline $\begin{array}{l}\text { Organizational Citizenship } \\
\text { Behavior }\end{array}$ & 0.79 & 0.81 \\
\hline Witnessed Incivility & 0.89 & 0.89 \\
\hline extrinsic motivation & 0.91 & 0.91 \\
\hline
\end{tabular}

\subsection{Validity}

According to Carmines and Zeller (1979), discriminant validity can be defined as "any single construct, when differs from other constructs in the model". Discriminate validity outcomes are acceptable when the constructs are taking an AVE loading more than 0.5 which implies that at least $50 \%$ of the variance was taken by the construct (Chin, 1998). Discriminant validity is recognized if the components which are in oblique are ominously greater than those values in off-diagonal in the parallel rows and columns. Discriminant Validity tests are being piloted in order to see if non-related concepts or extents are in fact distinct or not. An effective assessment of discriminant acceptability establishes that a sample of an idea isn't outstandingly linked with numerous tests envisioned to enumerate theoretically various ideas.

In our model, the value of AVE for intrinsic motivation was 0.73 (see table 3) but for remaining variables, it was less $<0.5$ (see table 4). However, if $\mathrm{AVE}<0.5$ but composite reliability is $>0.6$ than validity is still adequate (Fornell \& Larcker, 1981). In our model, the composite reliabilities of the variables ranged from 0.81 to 0.92 (see table 3 ). 
Table 3. Composite reliabilities and AVE of the variables

\begin{tabular}{|l|l|l|}
\hline Variables & Composite Reliability & $\begin{array}{l}\text { Average } \\
\text { Extracted (AVE) }\end{array}$ \\
\hline Emotional Exhaustion & 0.86 & 0.48 \\
\hline Experienced Incivility & 0.87 & 0.36 \\
\hline Instigated Incivility & 0.9 & 0.43 \\
\hline Intrinsic Motivation & 0.89 & 0.73 \\
\hline Job Satisfaction & 0.88 & 0.42 \\
\hline $\begin{array}{l}\text { Organizational Citizenship } \\
\text { Behavior }\end{array}$ & 0.81 & 0.33 \\
\hline Witnessed Incivility & 0.91 & 0.45 \\
\hline extrinsic motivation & 0.92 & 0.49 \\
\hline
\end{tabular}

\subsection{Model Fit Measures}

The fitness of the model in SEM-PLS is distinct by numerous methods, for example, standardized root-mean-square residual (SRMR), and the exact model fit like Normed Fit Index (NFI), d_ULS, $\chi 2$ (Chi-square) and d_G. The model fit measures comprising the measured value of both saturated-model as well as the estimated model (see table 4). The saturated model evaluates the correlation between all constructs. Whereas, the estimated model takes a model arrangement into account and is based on the total outcome arrangement. The value of SRMR was 0.9, NFI was 0.5 and RMS-Theta 0.9 were recorded. However, NFI and Chi-square has been poor criteria of model fit (Hu, 1999). On the basis of SRMR and RMS-theta, evidences of convergent validity are normal. 
Table 4. Validity measures of the model

\begin{tabular}{|l|l|l|}
\hline Measures & Saturated Model & Estimated Model \\
\hline SRMR & 0.07 & 0.09 \\
\hline d_ULS & 15.18 & 24.97 \\
\hline d_G & 4.92 & 5.28 \\
\hline Chi-Square & $6,243.93$ & $6,509.14$ \\
\hline NFI & 0.52 & 0.5 \\
\hline Rms_theta & & 0.09 \\
\hline
\end{tabular}

\subsection{Structural Modeling (Testing Hypothesis)}

The hypothesis was tested using the bootstrapping function (see table 5) of PLS-SEM software. The criteria on which the hypothesis tested was two-tailed p-value testing (Fisher, 1925). The confidence interval used as $\alpha$ was 0.1 as recommended by Fisher (1925), according to whom $0.1,0.05, .0 .01$ and 0.001 can be used as $\alpha$ when conducting a significance test.

Table 5. Significance testing values of the model

\begin{tabular}{|l|l|l|l|l|l|}
\hline Relationships & $\begin{array}{l}\text { Original } \\
\text { Sample } \\
(\mathrm{O})\end{array}$ & $\begin{array}{l}\text { Sample } \\
\text { Mean } \\
(\mathrm{M})\end{array}$ & $\begin{array}{l}\text { Standard } \\
\text { Deviation } \\
(\text { STDEV })\end{array}$ & $\begin{array}{l}\text { T } \\
\text { Statistics } \\
(\mid \mathrm{O} / \mathrm{STD} \\
\text { EV } \mid)\end{array}$ & $\begin{array}{l}\mathrm{P} \\
\text { Values }\end{array}$ \\
\hline $\begin{array}{l}\text { Emotional Exhaustion -> Job } \\
\text { Satisfaction }\end{array}$ & -0.26 & -0.27 & 0.06 & 4.59 & 0 \\
\hline Experience(EI) -> Job Satisfaction & 0.1 & 0.1 & 0.06 & 1.73 & 0.08 \\
\hline $\begin{array}{l}\text { Experience(II) -> Job Satisfaction } \\
\text { Experienced Incivility -> Emotional } \\
\text { Exhaustion }\end{array}$ & -0.28 & 0.29 & 0.09 & 3.06 & 0 \\
\hline $\begin{array}{l}\text { Experienced Incivility -> Intrinsic } \\
\text { Motivation }\end{array}$ & 0.05 & 0.05 & 0.09 & 0.09 & 0.06 \\
\hline
\end{tabular}




\begin{tabular}{|c|c|c|c|c|c|}
\hline $\begin{array}{llll}\text { Experienced } & \text { Incivility } & \rightarrow & \text { Job } \\
\text { Satisfaction } & & & \end{array}$ & -0.1 & -0.1 & 0.07 & 1.38 & 0.17 \\
\hline $\begin{array}{l}\text { Experienced Incivility -> } \\
\text { Organizational Citizenship Behavior }\end{array}$ & 0.34 & 0.35 & 0.1 & 3.46 & 0 \\
\hline $\begin{array}{l}\text { Experienced Incivility }->\text { extrinsic } \\
\text { motivation }\end{array}$ & -0.01 & -0.02 & 0.1 & 0.14 & 0.89 \\
\hline Gender(WI) -> Job Satisfaction & 0.14 & 0.13 & 0.04 & 3.07 & 0 \\
\hline $\begin{array}{l}\text { Instigated Incivility }->\text { Emotional } \\
\text { Exhaustion }\end{array}$ & 0.14 & 0.14 & 0.08 & 1.76 & 0.08 \\
\hline $\begin{array}{l}\text { Instigated Incivility } \rightarrow \text { Intrinsic } \\
\text { Motivation }\end{array}$ & -0.28 & -0.29 & 0.08 & 3.8 & 0 \\
\hline $\begin{array}{llll}\text { Instigated } & \text { Incivility } & \rightarrow & \text { Job } \\
\text { Satisfaction } & & & \end{array}$ & 0.06 & 0.06 & 0.07 & 0.9 & 0.37 \\
\hline $\begin{array}{l}\text { Instigated Incivility -> Organizational } \\
\text { Citizenship Behavior }\end{array}$ & -0.34 & -0.34 & 0.11 & 2.98 & 0 \\
\hline $\begin{array}{l}\text { Instigated Incivility } \rightarrow \text { extrinsic } \\
\text { motivation }\end{array}$ & -0.1 & -0.11 & 0.08 & 1.31 & 0.19 \\
\hline 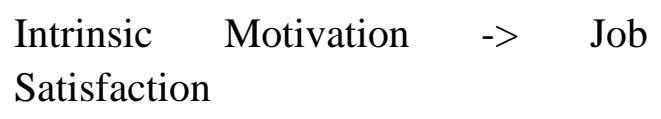 & 0.17 & 0.17 & 0.08 & 2.23 & 0.03 \\
\hline $\begin{array}{l}\text { Organizational Citizenship Behavior } \\
\text {-> Job Satisfaction }\end{array}$ & 0.03 & 0.03 & 0.07 & 0.47 & 0.64 \\
\hline $\begin{array}{l}\text { Witnessed Incivility } \rightarrow \text { Emotional } \\
\text { Exhaustion }\end{array}$ & 0.01 & 0.01 & 0.08 & 0.13 & 0.9 \\
\hline $\begin{array}{l}\text { Witnessed Incivility } \quad->\text { Intrinsic } \\
\text { Motivation }\end{array}$ & -0.07 & -0.08 & 0.08 & 0.94 & 0.35 \\
\hline $\begin{array}{llll}\text { Witnessed } & \text { Incivility } & \rightarrow & \text { Job } \\
\text { Satisfaction } & & & \end{array}$ & -0.11 & -0.11 & 0.06 & 1.89 & 0.06 \\
\hline Witnessed & -0.09 & -0.1 & 0.11 & 0.84 & 0.4 \\
\hline
\end{tabular}




\begin{tabular}{|c|c|c|c|c|c|}
\hline Organizational Citizenship Behavior & & & & & \\
\hline $\begin{array}{l}\text { Witnessed Incivility } \rightarrow \text { extrinsic } \\
\text { motivation }\end{array}$ & -0.08 & -0.08 & 0.08 & 0.94 & 0.35 \\
\hline $\begin{array}{llll}\text { extrinsic motivation } & \rightarrow & \text { Job } \\
\text { Satisfaction } & & & \end{array}$ & 0.24 & 0.24 & 0.07 & 3.52 & 0 \\
\hline $\begin{array}{l}\text { Experienced Incivility -> Emotional } \\
\text { Exhaustion -> Job Satisfaction }\end{array}$ & -0.07 & -0.08 & 0.03 & 2.43 & 0.02 \\
\hline $\begin{array}{l}\text { Instigated Incivility }->\text { Emotional } \\
\text { Exhaustion -> Job Satisfaction }\end{array}$ & -0.04 & -0.04 & 0.02 & 1.62 & 0.1 \\
\hline $\begin{array}{l}\text { Witnessed Incivility -> Emotional } \\
\text { Exhaustion -> Job Satisfaction }\end{array}$ & 0 & 0 & 0.02 & 0.12 & 0.9 \\
\hline $\begin{array}{l}\text { Experienced Incivility -> Intrinsic } \\
\text { Motivation -> Job Satisfaction }\end{array}$ & 0.01 & 0.01 & 0.02 & 0.49 & 0.63 \\
\hline $\begin{array}{l}\text { Instigated Incivility } \quad->\text { Intrinsic } \\
\text { Motivation }->\text { Job Satisfaction }\end{array}$ & -0.05 & -0.05 & 0.02 & 1.98 & 0.05 \\
\hline $\begin{array}{l}\text { Witnessed Incivility } \rightarrow \text { Intrinsic } \\
\text { Motivation }->\text { Job Satisfaction }\end{array}$ & -0.01 & -0.01 & 0.02 & 0.77 & 0.44 \\
\hline $\begin{array}{l}\text { Experienced Incivility -> } \\
\text { Organizational Citizenship Behavior } \\
\text {-> Job Satisfaction }\end{array}$ & 0.01 & 0.01 & 0.03 & 0.45 & 0.65 \\
\hline $\begin{array}{l}\text { Instigated Incivility }->\text { Organizational } \\
\text { Citizenship Behavior } \rightarrow \text { Job } \\
\text { Satisfaction }\end{array}$ & -0.01 & -0.01 & 0.03 & 0.44 & 0.66 \\
\hline $\begin{array}{l}\text { Witnessed Incivility } \quad-> \\
\text { Organizational Citizenship } \\
\text {-> Job Satisfaction }\end{array}$ & 0 & 0 & 0.01 & 0.28 & 0.78 \\
\hline $\begin{array}{l}\text { Experienced Incivility }->\text { extrinsic } \\
\text { motivation } \rightarrow \text { Job Satisfaction }\end{array}$ & 0 & 0 & 0.02 & 0.13 & 0.9 \\
\hline Instigated Incivility $\rightarrow$ extrinsic & -0.03 & -0.03 & 0.02 & 1.13 & 0.26 \\
\hline
\end{tabular}




\begin{tabular}{|l|l|l|l|l|l|}
\hline motivation -> Job Satisfaction & & & & & \\
\hline $\begin{array}{l}\text { Witnessed Incivility -> extrinsic } \\
\text { motivation -> Job Satisfaction }\end{array}$ & -0.02 & -0.02 & 0.02 & 0.87 & 0.39 \\
\hline
\end{tabular}

Table Notes: EI: Experienced incivility, II: Instigated incivility, WI: Witnessed incivility

$* * \mathrm{p}$-value $<0.1$

The SEM bootstrapping result showed a negative effect of EI on OCB and had a reasonable fit. The direct negative effect of EI on OCB was accepted $(S D=0.1$, T-Value=3.46, $p=0.0)$. Thus, we pass to reject the null hypothesis. There exists a negative effect of experienced incivility on intrinsic motivation but had no reasonable fit. The direct negative effect of experienced incivility on intrinsic motivation was rejected $(\mathrm{SD}=0.09$, $\mathrm{T}$-Value $=0.53, \mathrm{p}=$ 0.53). Thus, we failed to reject the null hypothesis. Whereas, result showed a negative effect of experienced incivility on extrinsic motivation but had no reasonable fit. The direct negative effect of experienced incivility on extrinsic motivation was rejected $(\mathrm{SD}=0.1$, $\mathrm{T}$-Value $=0.14, \mathrm{p}=0.89$ ). Thus, we failed to reject the null hypothesis. In relation to the evidences from literature, the results showed a positive effect of EI on EE and had a reasonable fit. The direct positive effect of $\mathrm{EI}$ on $\mathrm{EE}$ was accepted $(\mathrm{SD}=0.09$, T-Value $=3.06$, $\mathrm{p}=0.0$ ). Thus, we pass to reject the null hypothesis. The result showed a negative effect of II on OCB and had a reasonable fit. The direct negative effect of instigated incivility on OCB was accepted $(\mathrm{SD}=0.11, \mathrm{~T}-$ Value $=2.98, \mathrm{p}=0.0)$. Thus, we pass to reject the null hypothesis. Whereas, result showed a negative effect of instigated incivility on intrinsic motivation and had a reasonable fit. The direct negative effect of instigated incivility on intrinsic motivation was accepted $(\mathrm{SD}=0.08$, T-Value $=3.8, \mathrm{p}=0.0)$. Thus, we pass to reject the null hypothesis. However, the result showed a negative effect of instigated incivility on extrinsic motivation but had no reasonable fit. The direct negative effect of instigated incivility on extrinsic motivation was rejected $(\mathrm{SD}=0.08, \mathrm{~T}-$ Value $=1.31, \mathrm{p}=0.19)$. Thus, we failed to reject the null hypothesis. In accordance with the result, a positive effect of II reflects on emotional exhaustion and had a reasonable fit. The direct positive effect of instigated incivility on organizational citizenship behavior was accepted $(\mathrm{SD}=0.08$, T-Value $=1.76, \mathrm{p}=0.08)$. Thus, we pass to reject the null hypothesis. The result also implied that there exists a negative effect of witnessed incivility on OCB but had no reasonable fit. The direct negative effect of experienced incivility on organizational citizenship behavior was rejected $(\mathrm{SD}=0.11$, $\mathrm{T}$-Value $=0.84, \mathrm{p}=0.4$ ). Thus, we failed to reject the null hypothesis. Whereas, result showed a negative effect of witnessed incivility on intrinsic motivation but had no reasonable fit. The direct negative effect of witnessed incivility on intrinsic motivation was rejected $(\mathrm{SD}=0.08$, $\mathrm{T}$-Value $=0.94, \mathrm{p}=0.35$ ). Thus, we failed to reject the null hypothesis. Further, the result showed a negative effect of witnessed incivility on extrinsic motivation but had no reasonable fit. The direct negative effect of witnessed incivility on extrinsic motivation was rejected $(\mathrm{SD}=0.08, \mathrm{~T}-$ Value $=0.94, \mathrm{p}=0.35)$. Thus, we failed to reject the null hypothesis. However, the result showed a positive effect of witnessed incivility on EE but had no reasonable fit. The direct positive effect of witnessed incivility on emotional exhaustion was rejected (SD= 
$0.08, \mathrm{~T}-$ Value $=0.13, \mathrm{p}=0.9)$. Thus, we failed to reject the null hypothesis.

The SEM bootstrapping result showed a negative effect of EI on JS but had no reasonable fit. The direct negative effect of EI on JS was rejected $(\mathrm{SD}=0.07$, T-Value $=1.38, \mathrm{p}=0.17)$. Thus, we failed to reject the null hypothesis. The result also showed that there exists a negative effect of II on JS but had no reasonable fit. The direct negative effect of II on JS was rejected $(\mathrm{SD}=0.07, \mathrm{~T}-$ Value $=0.9, \mathrm{p}=0.37)$. Thus, we failed to reject the null hypothesis. According to the result, there is a negative effect of witnessed incivility on JS and had a reasonable fit. The direct negative effect of witnessed incivility on $\mathrm{JS}$ was accepted $(\mathrm{SD}=0.06, \mathrm{~T}$-Value $=1.89$, $\mathrm{p}=0.06$ ). Thus, we pass to reject the null hypothesis. Whereas, result showed a positive effect of OCB on JS but had no reasonable fit. The direct positive effect of OCB on JS was rejected $(\mathrm{SD}=0.07$, $\mathrm{T}-$ Value $=0.47, \mathrm{p}=0.64)$. Thus, we failed to reject the null hypothesis. However, the mediating effect of OCB on the relationship between EI and JS showed an indirect effect of OCB on the relationship of EI and JS but had no reasonable fit. The indirect effect of OCB on the relationship of EI and JS was rejected $(\mathrm{SD}=0.03$, T-Value $=0.45, \mathrm{p}=0.65)$. Thus, we failed to reject the null hypothesis. Referring to the mediating effect of OCB on the relationship between II and JS. The SEM bootstrapping showed an indirect effect of OCB on the relationship between II and JS but had no reasonable fit. The indirect effect of OCB on the relationship of II and JS was rejected ( $\mathrm{SD}=0.03$, T-Value $=0.44, \mathrm{p}=0.66)$. Thus, we failed to reject the null hypothesis. Whereas, the mediating effect of OCB on the relationship between witnessed incivility and JS. The SEM bootstrapping showed an indirect effect of OCB on the relationship of witnessed incivility and JS but had no reasonable fit. The indirect effect of OCB on the relationship of witnessed incivility and JS was rejected $(\mathrm{SD}=0.01$, $\mathrm{T}-$ Value $=0.28, \mathrm{p}=0.78$ ). Thus, we failed to reject the null hypothesis.

The SEM bootstrapping result showed a positive effect of IM on JS and had a reasonable fit. The direct positive effect of IM on JS was accepted $(\mathrm{SD}=0.08$, T-Value $=2.23, \mathrm{p}=0.03)$. Thus, we pass to reject the null hypothesis. In the case of the mediating effect of IM on the relationship between EE and JS, the SEM bootstrapping showed an indirect effect of IM on the relationship of EI and JS but had no reasonable fit. The indirect effect of IM on the relationship of EI and JS was rejected $(\mathrm{SD}=0.02$, T-Value $=0.49, \mathrm{p}=0.63)$. Thus, we failed to reject the null hypothesis. Concerning to the mediating effect of IM on the relationship between II and JS. The SEM bootstrapping showed an indirect effect of II on the relationship between II and JS and had a reasonable fit. The indirect effect of IM on the relationship between II and JS was accepted $(\mathrm{SD}=0.02$, T-Value $=1.98, \mathrm{p}=0.05)$. Thus, we pass to reject the null hypothesis. However, the mediating effect of IM on the relationship between witnessed incivility and JS showed an indirect effect of IM on the relationship of witnessed incivility and JS but had no reasonable fit. The indirect effect of IM on the relationship of witnessed incivility and JS was rejected $(\mathrm{SD}=0.02$, T-Value $=0.77, \mathrm{p}=0.44)$. Thus, we failed to reject the null hypothesis.

The result showed a positive effect of EM on JS and had a reasonable fit. The direct positive effect of EM on JS was accepted $(\mathrm{SD}=0.07$, T-Value $=3.52, \mathrm{p}=0.0)$. Thus, we pass to reject the null hypothesis. Whereas, the mediating effect of EM on the relationship between EI and JS showed an indirect effect of EM on the relationship of EI and JS but had no reasonable fit. 
The indirect effect of EM on the relationship of EI and JS was rejected $(\mathrm{SD}=0.02, \mathrm{~T}-\mathrm{Value}=$ $0.13, \mathrm{p}=0.9$ ). Thus, we failed to reject the null hypothesis. However, the mediating effect of EM on the relationship between II and JS. The SEM bootstrapping showed an indirect effect of EM on the relationship between II and JS but had no reasonable fit. The indirect effect of $\mathrm{EM}$ on the relationship of II and JS was rejected $(\mathrm{SD}=0.02$, T-Value $=1.13, \mathrm{p}=0.26)$. Thus, we failed to reject the null hypothesis. In the context of the mediating effect of EM on the relationship between witnessed incivility and JS, the SEM bootstrapping showed an indirect effect of EM on the relationship between witnessed incivility and JS but had no reasonable fit. The indirect effect of EM on the relationship of witnessed incivility and JS was rejected (SD= 0.02 , $\mathrm{T}-$ Value $=0.87, \mathrm{p}=0.39$ ). Thus, we failed to reject the null hypothesis.

The SEM bootstrapping result showed a negative effect of EE on JS and had a reasonable fit. The direct negative effect of EE on JS was accepted $(\mathrm{SD}=0.06$, T-Value $=4.59, \mathrm{p}=0.0)$. Thus, we pass to reject the null hypothesis. In the case of the mediating effect of EE on the relationship between EI and JS, the SEM bootstrapping showed an indirect effect of EE on the relationship between EI and JS and had a reasonable fit. The indirect effect of EE on the relationship of EI and JS was accepted $(\mathrm{SD}=0.03$, T-Value $=2.43, \mathrm{p}=0.02)$. Thus, we pass to reject the null hypothesis. Whereas, the mediating effect of EE on the relationship between II and JS, the SEM bootstrapping showed an indirect effect of EE on the relationship of II and JS and had a reasonable fit. The indirect effect of EE on the relationship between II and JS was accepted $(\mathrm{SD}=0.02$, $\mathrm{T}$-Value $=1.62, \mathrm{p}=0.1)$. Thus, we pass to reject the null hypothesis. However, the mediating effect of EE on the relationship between witnessed incivility and JS showed an indirect effect of EE on the relationship between witnessed incivility and JS but had not a reasonable fit. The indirect effect of EE on the relationship of witnessed incivility and JS was rejected $(\mathrm{SD}=0.02, \mathrm{~T}-$ Value $=0.12, \mathrm{p}=0.9)$. Thus, we failed to reject the null hypothesis. The moderating effect of gender on the relationship between EI and JS. The SEM bootstrapping calculated the moderating effect of gender on the relationship of EI and JS but had no reasonable fit. The moderating effect of gender on the relationship of EI and JS was rejected $(\mathrm{SD}=0.08, \mathrm{~T}$-Value $=1.23, \mathrm{p}=0.22)$. Thus, we failed to reject the null hypothesis. However, the moderating effect of gender on the relationship between II and JS. The SEM bootstrapping calculated the moderating effect of gender on the relationship between II and JS but had no reasonable fit. The moderating effect of gender on the relationship of II and JS was rejected $(\mathrm{SD}=0.1, \mathrm{~T}$-Value $=1.56, \mathrm{p}=0.12)$. Thus, we failed to reject the null hypothesis.

In the case of the moderating effect of gender on the relationship between witnessed incivility and JS, the SEM bootstrapping calculated the moderating effect of gender on the relationship of witnessed incivility and JS and had a reasonable fit. The moderating effect of gender on the relationship of witnessed incivility and JS was accepted $(\mathrm{SD}=0.04$, T-Value $=3.07, \mathrm{p}=0)$. Thus, we pass to reject the null hypothesis. Whereas, the moderating effect of years of experience on the relationship between EI and JS, The SEM bootstrapping calculated the moderating effect of years of experience on the relationship of EI and JS and had a reasonable fit. The moderating effect of years of experience on the relationship between EI and JS was accepted $(\mathrm{SD}=0.06, \mathrm{~T}-$ Value $=1.73, \mathrm{p}=0.08)$. Thus, we pass to reject the null hypothesis. However, the moderating effect of years of experience on the relationship 


\section{Macrothink}

between II and JS, SEM bootstrapping calculated the moderating effect of years of experience on the relationship of II and JS but had no reasonable fit. The moderating effect of years of experience on the relationship between II and JS was rejected ( $\mathrm{SD}=0.06$, T-Value= $1.36, \mathrm{p}=0.17)$. Thus, we failed to reject the null hypothesis. Lastly, the moderating effect of years of experience on the relationship between witnessed incivility and JS, bootstrapping calculated the moderating effect of years of experience on the relationship of witnessed incivility and JS but had no reasonable fit. The moderating effect of years of experience on the relationship of witnessed incivility and JS was rejected $(\mathrm{SD}=0.08, \mathrm{~T}-$ Value $=0.03, \mathrm{p}=$ 0.98). Thus, we failed to reject the null hypothesis.

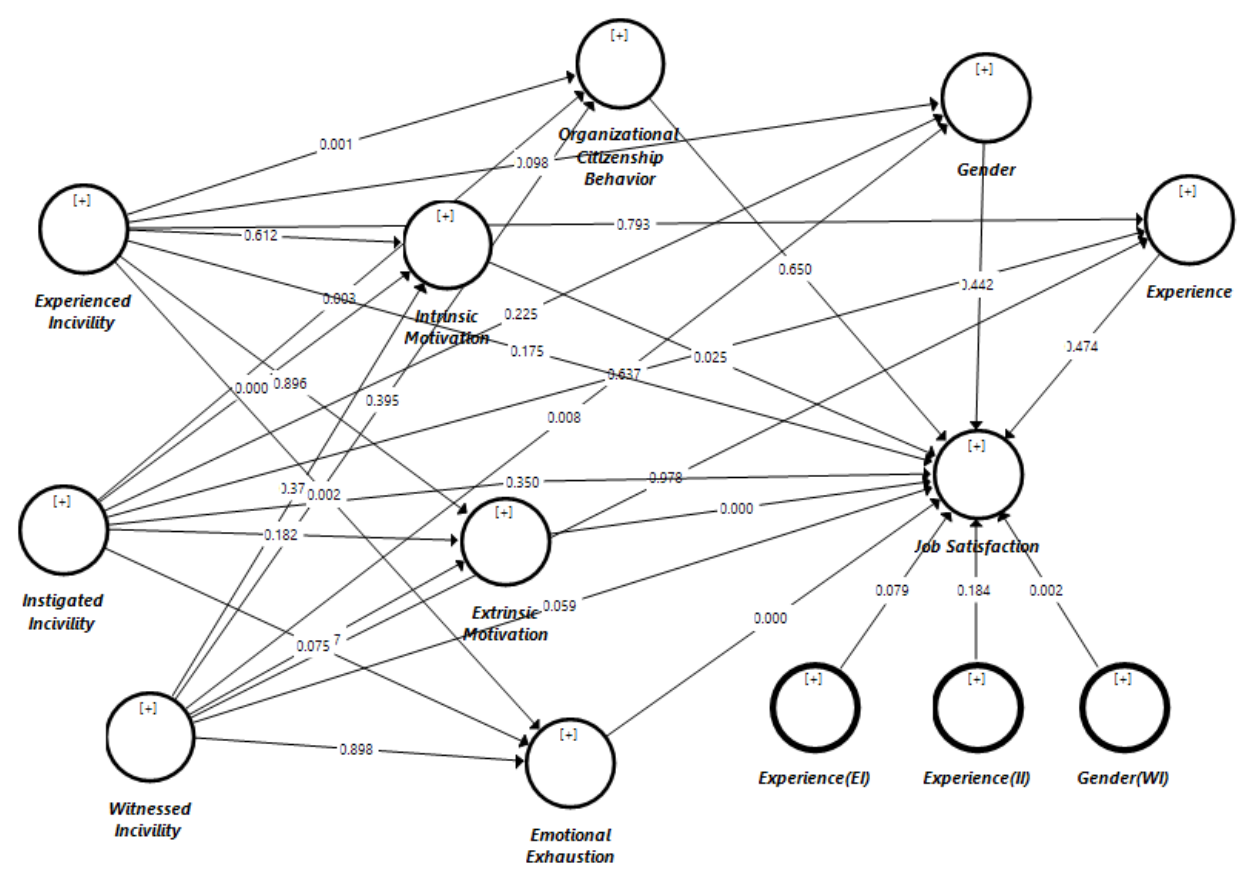

Figure 2. Hypothesized model with p values

\section{Discussion}

This was an investigative study where a model of workplace incivility and its corresponding mediators and moderators were tested as supported by the shreds of evidence from the past. The model, as depicted in figure 2, portrayed the impact of WI on JS in the presence of OCB, IM, EM, and EE as mediators. The model also portrayed the presence of gender and year of experiences as moderators. However, the results did not fully support the model. There was no direct relationship between WI and JS. However, in the presence of EE, the relationship between EI, II, and JS was significant. Thus, results fully supported the argument that EE has mediated the relationship. The results implied that witnessing incivility has no impact on JS neither it is mediated by any of the mediators tested. Another important highlight of the results was that OCB and EM had no mediating impact on the relationship of WI and JS, this was due to the fact that OCB had no direct impact on JS. 
Our research implied that experiencing incivility causes emotional exhaustion at the workplace and leads to job dissatisfaction, however witnessing incivility had no impact on job satisfaction. This could be the result of our culture that is prevalent in the organizations operating in Pakistan. It was also a fact that people having greater years of experience, experienced a greater level of workplace incivility and years of experience moderated the relationship between experience incivility and job satisfaction. Secondly, it was astonishing to see that witnessing incivility in terms of gender had different effects on job satisfaction. As compared to males, the females who witnessed incivility had a greater tendency of having job dissatisfaction.

Intrinsic motivation proved to be a factor reducing workplace incivility at the workplace, however, OCB and extrinsic motivation had no effects on the relationship of workplace incivility and job satisfaction. We encourage researchers to continue testing the hypothesized model in larger regional aspects and it should also be tested in a different cultural context. Practical implications imply that management should intervene in reducing uncivil behavior at the workplace because it can spiral throughout the workplace and impact the organization's bottom line (Harold, 2015).

It is important for organizations to provide adequate attention towards such complex behavioral aspects which makes the culture of the organization. The results have strongly supported the argument that WI is sometimes an undeliberate action which can harm the performance of the employees, yet it can be judged and analyzed via various means. The empirical evidences had a strong basis to theorize that experiencing workplace incivility causes the depletion of OCB in employee's behaviors mainly due to the fact that workplace incivility causes depression and paranoia which leads to reduced exhibition of OCBs. However, workplace incivility tends to decrease the desire of work enjoyment in order to protect employee's resources of intrinsic factors. This provided strong empirical evidences to theorize that experiencing incivility has detrimental effects on employees psychologically. These negative psychological effects cause employees to lose internal factors of motivation. The research also implied that extrinsic motivation refers to the monetary benefits which in any way cannot be impacted by the incivility. This relationship was theorized on the basis of Maslow's hierarchy of need in context of organizational atmosphere. The lowest level of hierarchy reveals that basic pay or monetary factors are the primary basis of employment, thus the cultural context is secondary to an employee and workplace incivility doesn't harm, in any way, the extrinsic motivational factors. According to the theorized viewpoint of incivility and emotional exhaustion, WI is a source of psychological and mental distress at workplace, experiencing incivility depletes the emotional resources of employees and causes burnout and exhaustion, and hence workplace incivility is chaotic for emotional resources and causes employees to feel emotionally exhausted. The results of the research had been in line with empirical evidences provided from the past, on the other hand they had been contrary to the cultural context and can vary from region to region.

The model is satisfactory in nature because the results provided strong shreds of evidence of discriminant and convergent validity of the model and constructs. The constructs used to record the responses also had strong reliability and validity. Thus, it is implied that the model 
and constructs had no flaw and were unbiased in the result. The outcomes of the current research had depicted the essence of culture in organizations that are operating in Pakistan, particularly in Karachi. Hence, it is important to note that the model of the present study can have different implications and results in a diversified regional context.

\section{Conclusion}

WI is conceivably a persistent root of disruptive behavior at the workplace. To evaluate WI occurrence, Cortina et al. (2008) worked in an array of work settings in which; the incidence rates they revealed exemplify the ubiquity of this dilemma. For example, 79\% of a law enforcement sample, $71 \%$ of a court employee data, $75 \%$ of a university employee data (Cortina et al., 2001; Cortina \& Magley, 2009) asserted that they had experienced some form of uncivil behavior at work in recent years. Other than that, researchers have affirmed similarly high rates of correlated workplace misconducts. In sum, preceding researches have positioned substantial grounds in explaining WI, demarcating its influence, and enunciating its liaison to other taxonomies of generalized antagonism in the workplace.

According to Porath and Pearson (2013), experiencing incivility at the workplace has detrimental consequences for individuals and cost organizations adversely. The results of this research suggested that experiencing WI causes EE and psychological stress and leads to job dissatisfaction. The prevalence of uncivil behavior causes employees to feel emotionally drained and gets less productive (Maslach, 1981). However, the research implied that witnessing incivility has no impact on job satisfaction. Workplace incivility spreads like a virus, once it creeps into the organization, organizations should take measures to reduce workplace incivility (Harold, 2015).

The results of the research implied that organizations may take in to account, the delinquent and significance of WI at the administrative level. The present research ought to provide implications of how workplace incivility does not unswervingly impact JS. EE, on the other hand, has been revealed to link WI and JS. Allowing for the influences concerning to the mediating influence of OCB and motivation between WI and employee JS, it will allow firms to cogitate instituting organized institutional practices and strategies to avert employees from sensing emotionally exhausted as a consequence of WI (Ferguson, 2012). With the help of findings of this research, organizations might establish T\&D programs to aid targets of WI such as psychoanalysis and stress management training as may be the case (Ferguson, 2012). As suggested by Anderson and Pearson (1999), in order to alleviate stress tolerance among employees, organizations might introduce their own human resource hotlines, conflict mediators or fitness centers. Strategic management teams, on the basis of research, can also introduce firm strategies and guidelines intended at cultivating required behaviors among organizational associates in order to protect targets of WI. Beyond these policies and rules, they would be prudent to proactively improve corporate culture which uplifts empathetic acts and guards against WI.

\section{Future Recommendations and Limitations}

Although the research has numerous practical and theoretical implications, it is important to 
mention the limitations of the present work. Firstly, time to conduct research was very short due to which longitudinal study was not performed. Secondly, lack of resources caused the data to be less diversified, it can be extended to different countries. Lastly, the use of cross-sectional self-reports raises concerns regarding common method bias (CMB), it is recommended to be cautious when performing causal relationships between variables.

Future studies might use the existing model to conduct research in intercontinental or inter-country regions to get a more diversified view of the theoretical model. Secondly, a longitudinal study can be performed in this regard, to avoid CMB and to capture the changing behavior of respondents. Lastly, organizational and societal culture and norms should be tested as moderators among incivility and job satisfaction in order to verify any biased effects of regular norms and behaviors.

\section{References}

Aiken, L. H., Clarke, S. P., Sloane, D. M., Sochalski, J., \& Silber, J. H. (2002). Hospital nurse staffing and patient mortality, nurse burnout, and job dissatisfaction. Jama, 288(16), 1987-1993. https://doi.org/10.1001/jama.288.16.1987

Amabile, T. M. (1996). Creativity in context (Boulder, CO, Westview Press).

Andersson, L. M., \& Pearson, C. M. (1999). Tit for tat? The spiraling effect of incivility in the workplace. Academy of management review, 24(3), 452-471. https://doi.org/10.5465/amr.1999.2202131

Aquino, K., \& Bommer, W. H. (2003). Preferential mistreatment: How victim status moderates the relationship between organizational citizenship behavior and workplace victimization. Organization $\quad$ Science, $\quad$ 374-385. https://doi.org/10.1287/orsc.14.4.374.17489

Aquino, K., \& Thau, S. (2009). Workplace victimization: Aggression from the target's $\begin{array}{llll}\text { perspective. Annual of } & \text { review }\end{array}$ https://doi.org/10.1146/annurev.psych.60.110707.163703

Blau, G., \& Andersson, L. (2005). Testing a measure of instigated workplace incivility. Journal of Occupational and Organizational Psychology, 78(4), 595-614. https://doi.org/10.1348/096317905X26822

Bolino, M. C. (1999). Citizenship and impression management: Good soldiers or good actors? Academy of Management Review, 24(1), 82-98. https://doi.org/10.5465/amr.1999.1580442

Bunk, J. A., \& Magley, V. J. (2013). The role of appraisals and emotions in understanding experiences of workplace incivility. Journal of occupational health psychology, 18(1), 87. https://doi.org/10.1037/a0030987

Carmines, E. G., \& Zeller, R. A. (1979). Reliability and validity assessment, 17. Sage publications. https://doi.org/10.4135/9781412985642

Chihak, C. (2018). Faculty to faculty incivility in Iowa nursing education programs. 
Chin, W. W. (1998). The partial least squares approach to structural equation modeling. Modern methods for business research, 295(2), 295-336.

Cortina, L. M. (2008). Unseen injustice: Incivility as modern discrimination in organizations. Academy of management review, 33(1), 55-75. https://doi.org/10.5465/amr.2008.27745097

Cortina, L. M., \& Magley, V. J. (2009). Patterns and profiles of response to incivility in the workplace. Journal of occupational health psychology, 14(3), 272. https://doi.org/10.1037/a0014934

Cortina, L. M., Magley, V. J., Williams, J. H., \& Langhout, R. D. (2001). Incivility in the workplace: Incidence and impact. Journal of occupational health psychology, 6(1), 64. https://doi.org/10.1037/1076-8998.6.1.64

Dormann, C., \& Zapf, D. (2004). Customer-related social stressors and burnout. Journal of occupational health psychology, 9(1), 61. https://doi.org/10.1037/1076-8998.9.1.61

Ferguson, M. (2012). You cannot leave it at the office: Spillover and crossover of coworker incivility. Journal of Organizational Behavior, 33(4), 571-588. https://doi.org/10.1002/job.774

Fisher, R. A. (1925, July). Theory of statistical estimation. In Mathematical Proceedings of the Cambridge Philosophical Society, 22(5), 700-725. Cambridge University Press. https://doi.org/10.1017/S0305004100009580

Fornell, C., \& Larcker, D. F. (1981). Structural equation models with unobservable variables and measurement error: Algebra and statistics. https://doi.org/10.2307/3150980

Gagné, M., Forest, J., Gilbert, M. H., Aubé, C., Morin, E., \& Malorni, A. (2010). The motivation at work scale: Validation evidence in two languages. Educational and psychological measurement, 70(4), 628-646. https://doi.org/10.1177/0013164409355698

Hair, J. F., Sarstedt, M., Ringle, C. M., \& Mena, J. A. (2012). An assessment of the use of partial least squares structural equation modeling in marketing research. Journal of the academy of marketing science, 40(3), 414-433. https://doi.org/10.1007/s11747-011-0261-6

Harold, C. M., \& Holtz, B. C. (2015). The effects of passive leadership on workplace incivility. Journal of Organizational Behavior, 36(1), 16-38. https://doi.org/10.1002/job.1926

Hu, L. T., \& Bentler, P. M. (1999). Cutoff criteria for fit indexes in covariance structure analysis: Conventional criteria versus new alternatives. Structural equation modeling: a multidisciplinary journal, 6(1), 1-55. https://doi.org/10.1080/10705519909540118

Jawahar, I. M., \& Schreurs, B. (2018). Supervisor incivility and how it affects subordinates' performance: a matter of trust. Personnel Review. https://doi.org/10.1108/PR-01-2017-0022

Kim, T. Y., \& Shapiro, D. L. (2008). Retaliation against supervisory mistreatment. International Journal of Conflict Management. https://doi.org/10.1108/10444060810909293

Leiter, M. P., \& Maslach, C. (1988). The impact of interpersonal environment on burnout and 
organizational commitment. Journal of organizational behavior, 9(4), 297-308. https://doi.org/10.1002/job.4030090402

Lim, S., Cortina, L. M., \& Magley, V. J. (2008). Personal and workgroup incivility: impact on work and health outcomes. Journal of applied psychology, 93(1), 95. https://doi.org/10.1037/0021-9010.93.1.95

Lim, V. K., \& Teo, T. S. (2009). Mind your E-manners: Impact of cyber incivility on employees' work attitude and behavior. Information \& Management, 46(8), 419-425. https://doi.org/10.1016/j.im.2009.06.006

Macdonald, S., \& Maclntyre, P. (1997). The generic job satisfaction scale: Scale development and its correlates. Employee Assistance Quarterly, 13(2), 1-16. https://doi.org/10.1300/J022v13n02_01

Mao, C., Chang, C. H., Johnson, R. E., \& Sun, J. (2019). Incivility and employee performance, citizenship, and counterproductive behaviors: Implications of the social context. Journal of occupational health psychology, 24(2), 213. https://doi.org/10.1037/ocp0000108

Maslach, C., \& Jackson, S. E. (1981). The measurement of experienced burnout. Journal of organizational behavior, 2(2), 99-113. https://doi.org/10.1002/job.4030020205

Maslach, C., \& Jackson, S. E. (1981). Maslach burnout inventory: research edition; manual. Consulting psychologists press. https://doi.org/10.1037/t05190-000

Miner-Rubino, K., \& Cortina, L. M. (2004). Working in a context of hostility toward women: implications for employees' well-being. Journal of occupational health psychology, 9(2), 107. https://doi.org/10.1037/1076-8998.9.2.107

Miner-Rubino, K., \& Cortina, L. M. (2007). Beyond targets: Consequences of vicarious exposure to misogyny at work. Journal of Applied psychology, 92(5), 1254. https://doi.org/10.1037/0021-9010.92.5.1254

Montgomery, K., Kane, K., \& Vance, C. M. (2004). Accounting for differences in norms of respect: A study of assessments of incivility through the lenses of race and gender. Group \& Organization Management, 29(2), 248-268. https://doi.org/10.1177/1059601103252105

Nunnally, J. C., \& Bernstein, I. H. (1978). Psychometric Theory McGraw-Hill New York. The role of university in the development of entrepreneurial vocations: a Spanish study.

Organ, D. W. (1988). Organizational citizenship behavior: The good soldier syndrome. Lexington Books/DC Heath and Com.

Pearson, C. M., Andersson, L. M., \& Porath, C. L. (2000). Assessing and attacking workplace $\begin{array}{llll}\text { incivility. } & \text { Organizational } & \text { 123-137. }\end{array}$ https://doi.org/10.1016/S0090-2616(00)00019-X

Penney, L. M., \& Spector, P. E. (2005). Job stress, incivility, and counterproductive work behavior (CWB): The moderating role of negative affectivity. Journal of Organizational Behavior: The International Journal of Industrial, Occupational and Organizational 
Psychology and Behavior, 26(7), 777-796. https://doi.org/10.1002/job.336

Porath, C. L., \& Erez, A. (2009). Overlooked but not untouched: How rudeness reduces onlookers' performance on routine and creative tasks. Organizational Behavior and Human Decision Processes, 109(1), 29-44. https://doi.org/10.1016/j.obhdp.2009.01.003

Porath, C., \& Pearson, C. (2013). The price of incivility. Harvard business review, 91(1-2), 115-121.

Reio, T. G., \& Trudel, J. (2013). Workplace incivility and conflict management styles: Predicting job performance, organizational commitment and turnover intent. International Journal of Adult Vocational Education and Technology (IJAVET), 4(4), 15-37. https://doi.org/10.4018/ijavet.2013100102

Ringle, C. M., Sarstedt, M., Mitchell, R., \& Gudergan, S. P. (2018). Partial least squares structural equation modeling in HRM research. The International Journal of Human Resource Management, 1-27. https://doi.org/10.1080/09585192.2017.1416655

Ringle, C. M., Wende, S., \& Becker, J. M. (2015). SmartPLS 3. SmartPLS GmbH, Boenningstedt. J. of Serv. Sci. and Managm, 10(3).

Sakurai, K., \& Jex, S. M. (2012). Coworker incivility and incivility targets' work effort and counterproductive work behaviors: The moderating role of supervisor social support. Journal of Occupational Health Psychology, 17(2), 150. https://doi.org/10.1037/a0027350

Schilpzand, P., De Pater, I. E., \& Erez, A. (2016). Workplace incivility: A review of the literature and agenda for future research. Journal of Organizational behavior, 37, S57-S88. https://doi.org/10.1002/job.1976

Sliter, M., Sliter, K., \& Jex, S. (2012). The employee as a punching bag: The effect of multiple sources of incivility on employee withdrawal behavior and sales performance. Journal of Organizational Behavior, 33(1), 121-139. https://doi.org/10.1002/job.767

Spector, P. E., Bauer, J. A., \& Fox, S. (2010). Measurement artifacts in the assessment of counterproductive work behavior and organizational citizenship behavior: Do we know what we think we know?. Journal of Applied Psychology, 95(4), 781. https://doi.org/10.1037/a0019477

Spence Laschinger, H. K., Leiter, M., Day, A., \& Gilin, D. (2009). Workplace empowerment, incivility, and burnout: Impact on staff nurse recruitment and retention outcomes. Journal of nursing management, 17(3), 302-311. https://doi.org/10.1111/j.1365-2834.2009.00999.x

Taylor, S. G., Bedeian, A. G., \& Kluemper, D. H. (2012). Linking workplace incivility to citizenship performance: The combined effects of affective commitment and conscientiousness. Journal of Organizational Behavior, 33(7), 878-893. https://doi.org/10.1002/job.773

Torkelson, E., Holm, K., Bäckström, M., \& Schad, E. (2016). Factors contributing to the perpetration of workplace incivility: The importance of organizational aspects and 


\section{IIacrothink}

International Journal of Human Resource Studies

ISSN 2162-3058 2020, Vol. 10, No. 2

experiencing incivility from others. Work \& Stress, 30(2), 115-131. https://doi.org/10.1080/02678373.2016.1175524

Totterdell, P., Hershcovis, M. S., Niven, K., Reich, T. C., \& Stride, C. (2012). Can employees be emotionally drained by witnessing unpleasant interactions between coworkers? A diary study of induced emotion regulation. Work \& Stress, 26(2), 112-129. https://doi.org/10.1080/02678373.2012.681153

Tremblay, M. A., Blanchard, C. M., Taylor, S., Pelletier, L. G., \& Villeneuve, M. (2009). Work Extrinsic and Intrinsic Motivation Scale: Its value for organizational psychology research. Canadian Journal of Behavioural Science/Revue canadienne des sciences du comportement, 41(4), 213. https://doi.org/10.1037/a0015167

Yeung, A., \& Griffin, B. (2008). Workplace incivility: Does it matter in Asia. People and Strategy, 31(3), 14-19.

\section{Copyright Disclaimer}

Copyright for this article is retained by the author(s), with first publication rights granted to the journal.

This is an open-access article distributed under the terms and conditions of the Creative Commons Attribution license (http://creativecommons.org/licenses/by/4.0/). 